\title{
Eczema therapeutics in children: what do the clinical trials say?
}

\author{
Theresa NH Leung, KL Hon *
}

\section{A B S T R A C T}

Eczema or atopic dermatitis is a common childhood atopic disease associated with chronicity and impaired quality of life. As there is no cure for the disease, treatment relies on topical and systemic anti-allergic or immunomodulating therapies. Topical cortico-steroid, macrolide immunosuppressants, and oral immunomodulating drugs for recalcitrant disease have been the mainstay of therapy. Management of atopic dermatitis must consider the individual symptomatic variability of the disease. Basic therapy is focused on patient/ family education, hydrating topical treatment, and avoidance of specific and non-specific provocative factors. Anti-inflammatory treatment based on topical glucocorticosteroids and topical calcineurin inhibitors is used for exacerbation management and more recently in selective cases for proactive therapy. Systemic immunosuppressive treatment is an option for severe refractory cases. induce disease exacerbation and justify additional antimicrobial treatment. Adjuvant therapy includes ultraviolet (UV) irradiation preferably with UVA1 or narrowband UVB. Dietary recommendations should be specific and given only when food allergy is confirmed. Allergen-specific immunotherapy against aeroallergens may be useful in selected cases. Parallel use of traditional and proprietary topical and herbal medicine has also been popular in China and many cities in Asia. Complementary and alternative medicine may have a place but evidence-based data are lacking.

\section{Hong Kong Med J 2015;21:251-60}

DOl: $10.12809 / \mathrm{hkmj} 144474$

TNH Leung, FHKCPaed, FRCPCH

KL Hon *, MD, FCCM

Department of Paediatrics, The Chinese University of Hong Kong, 6/F, Clinical Sciences Building, Prince of Wales Hospital, Shatin, Hong Kong

Microbial colonisation and superinfection may * Corresponding author: ehon@cuhk.edu.hk

\section{Introduction}

Eczema or atopic dermatitis (AD) is a chronically relapsing dermatosis that affects $9 \%$ to $20 \%$ of children in the US and is more prevalent in children who belong to upper socio-economic classes, smaller family sizes, and families with overzealous hygiene ${ }^{1-7}$ The disease affects $5.6 \%$ of young children and $3.8 \%$ of school children and adolescents in Hong Kong. ${ }^{8,9}$

Children with $\mathrm{AD}$ may suffer from lack of sleep, irritability, daytime tiredness, emotional stress, lowered self-esteem, and psychological disturbance. ${ }^{10,11}$ The disruption of school, family life, and social interactions can severely impair the quality of life and extends beyond childhood. Parents may experience guilt, frustration, resentment, exhaustion, and helplessness due to their child's condition. ${ }^{12}$

The diagnosis of $\mathrm{AD}$ is predominantly clinical, based on a constellation of clinical features. Firm criteria to define AD were first established by Hanifin and Rajka. ${ }^{2,13}$ The UK working diagnostic criteria are also concise and practical. ${ }^{14}$

Atopic dermatitis involves defective cell- mediated immunity related to an imbalance in two subsets of CD4-T cells that creates a predominance of T-memory cells in the T-helper 2 pathways and preferential apoptosis of interferon-gamma producing $\mathrm{T}$-helper 1 memory and effector $\mathrm{T}$ cells. ${ }^{15,16}$ Recently, we demonstrated that AD also involves many cellular and humoral immune mediators in addition to an aberration of cellmediated immunity. ${ }^{17}$

There is a strong genetic predisposition. It has been shown that loss-of-function mutations in the filaggrin (filament-aggregating protein) $[F L G]$ gene predispose to $\mathrm{AD} .^{18-22}$ Recent findings have shown that the affected skin of atopic individuals is deficient in filaggrin degradation products. ${ }^{23,24}$

In summary, $\mathrm{AD}$ is an atopic/allergic disease that involves complex interactions among susceptible genes, immunological factors, skin barrier defects, infections, neuroendocrine factors, and environmental factors. ${ }^{2}$ Using clinical guidelines primarily but not exclusively from Europe, the US, Australia, Canada, Hong Kong, Korea and Japan, this paper summarises the contemporary therapeutics in management of childhood AD. 


\section{治療兒童濕疹：臨床試驗得出甚麼結論？ 梁銀河、韓錦倫}

濕疹或遺傳過敏性皮膚炎是兒童常見的過敏性皮膚病, 這種慢性病嚴 重影響他們的生活質素。由於濕疹不能治癒, 舒緩的方法一般會依賴 局部或全身性抗過敏或免疫調節療法。一直以來, 濕疹的主要方法為 外用皮質類固醇激素、免疫抑製劑大環內酯類, 以及在頑固性病例使 用口服免疫調節藥物。治理方案必須因應患者個別情況而決定。基本 療法強調對患者和家人的教育、外用保濕治療, 以及避免特殊性和非 特殊性的誘發因素。近年研究在合適病例施以外用糖皮質激素及外用 鍴調神經磷酸酶抑製劑的抗炎藥物可作積極長效治療, 以控制病情。 全身性免疫抑制治療是針對嚴重難治性病例的其中一種方法。感染可 能誘發濕疹發作, 此時必須加入抗菌藥物治療。輔助療法包括紫外線 照射, 其中首選為UVA1 或窄頻UVB。在確認食物過敏為濕疹發作的 誘因後, 才向患者作出具體的飲食建議。一些對吸入過敏原產生過敏 的患者, 針對性的減敏治療可能有用。在中國和其他許多亞洲地區, 同時使用傳統的和專有的中成藥治濕疹已經很流行。另類及替代醫學 療法可能有用, 可惜缺乏實證醫學的數據支持。

\section{Overview of atopic dermatitis therapeutic guidelines}

Reviews and guidelines on management of AD have been published by various professional organisations worldwide. ${ }^{25-37}$ Most of the guidelines have provided recommendations for both children and adults while the National Institute for Health and Care Excellence (NICE) Guidelines focus on management of AD for children of 12 years and younger. ${ }^{36,38}$ These evidence-based guidelines are regularly reviewed and updated. The NICE guidelines were reviewed in 2011 and 2014 with no new recommendations or changes. The American Academy of Dermatology first published the guidelines in 2004 and recently updated them in 2014 with a more comprehensive review that was divided into four sections with paediatric considerations highlighted in the section on management and treatment with phototherapy and systemic agents..$^{29-33,39}$ The new European Guidelines published in $2012^{27,28}$ evaluated existing evidence-based guidelines from Germany, the Health Technology Assessment Report, and the position statement of the European Task Force on Atopic Dermatitis ${ }^{26}$ together with an appraisal of updated literature to provide consensus recommendations for management. In 2013, the Hong Kong College of Paediatricians formed a panel group with paediatricians and dermatologists to agree on management guidelines of AD in children based on the NICE guidelines for children with recommendations for local practice. ${ }^{40}$

\section{Overview of individual treatment}

\section{Emollient}

Although emollients are widely recommended as the foundation in management of $\mathrm{AD}$, their use is supported by only limited evidence. ${ }^{41-45}$ There is no evidence to show that any emollient is superior to their counterparts. A small-scale randomised controlled trial (RCT) showed that over-the-counter petroleum-based skin protectant moisturiser for mild-to-moderate $\mathrm{AD}$ in children has similar clinical efficacy and much higher cost-efficacy than the glycyrrhetinic acid-containing barrier repair cream or a ceramide-dominant barrier repair cream. ${ }^{46}$ Recently concern has been raised about the possible adverse effects of sodium lauryl sulphate (SLS), a surfactant commonly found in many emollients like aqueous cream and emulsifying ointments. Aqueous cream has been shown to cause skin irritation, thinning of the cornea stratum, and increased transepidermal water loss following twice daily application for a few weeks. ${ }^{47-49}$ Hence, SLScontaining emollients are more suitable as a soap substitute rather than left-on emollients. There is a lack of evidence for other bathing practices like addition of emollients to bathing water, while use of emollients immediately after bathing as 'soak and seal' can help maintain hydration. ${ }^{30,45}$ Generally, liberal use of emollients is recommended but it is uncertain whether their use in between periods of eczema flare-up helps to prevent further deterioration and how different methods and timing of application of emollients influence their efficacy.

The Barrier Enhancement for Eczema Prevention research study (http://beepstudy.org) aims to find out whether skin care advice including application of emollients can prevent eczema in newborns. A pilot study identified 124 infants with high-risk factors for $\mathrm{AD}$ including more than one first-degree relative with a history of asthma, hay fever, or $\mathrm{AD}^{50}$ Subjects were randomised to receive once-daily application of an emollient before the age of 3 weeks and continuing for 6 months. The 6-month cumulative incidence of investigator-diagnosed eczema was $22 \%$ in the daily emollient group compared with $43 \%$ in controls corresponding to a relative risk reduction of $50 \% .^{50}$ Another prospective RCT to investigate whether protecting the skin barrier with a moisturiser during the neonatal period could prevent development of $\mathrm{AD}$ and allergic sensitisation showed that daily application of moisturiser during the first 32 weeks of life reduces the risk of $\mathrm{AD} /$ eczema in infants. $^{51}$ These reports suggest that use of emollients might prevent development of $\mathrm{AD}$ in high-risk patients.

\section{Topical corticosteroids}

Evidence for the use of topical corticosteroids (TCS) 
in the management of $\mathrm{AD}$ is well established. ${ }^{52}$ Topical corticosteroids are recommended as firstline anti-inflammatory therapy for $\mathrm{AD}$ in children and adults..$^{27,30,35,40}$ The TCS are classified in order of relative potency according to their vasoconstrictive effect. $^{30,40}$ Different formulations of the same agent affect the potency, with ointment, cream, and lotion in descending order of clinical efficacy. There are limited clinical studies to compare the different types of TCS and evidence for recommendations on dosage, frequency, and duration of application is sparse. The choice of type and formulation of TCS depends on a number of factors including severity and site of lesions, patient's age and preference. The NICE guidelines for children recommend use of the corresponding potency of TCS for severity of atopic eczema; mild potency for the face and neck and moderate potency only for short-term (3-5 days) use in severe flares; moderate or potent preparations for short periods only (7-14 days) for flares in vulnerable sites such as axillae and groin. ${ }^{36,53}$ Potent fluorinated corticosteroids should be avoided for infants and sensitive skin areas. ${ }^{34}$ Systematic reviews of studies that compared the frequency of application of newer-generation moderately potent to very potent steroids identified no benefit in outcome for more frequent applications over once-daily application. ${ }^{54}$ In general, TCS should be applied once daily and no more than twice daily. ${ }^{36,38,53}$ During acute flares, it is advisable to use the strength and potency of steroids appropriate to the severity of the eczema daily to gain rapid control of inflammation, reducing gradually with a less-potent steroid or less-frequent application.

Topical corticosteroids are generally safe with few serious reported adverse effects. ${ }^{55,56}$ Risks of side-effects increase with higher potency, occlusion, thinner skin areas, severity of $\mathrm{AD}$, young age, and longer duration of use. Local adverse effects include skin atrophy, telangiectasia, hypertrichosis, and striae. ${ }^{56}$ Skin absorption of TCS sufficient to cause clinical significant systemic adverse effects are rare. A systematic review of small-scale studies on the effects of hypothalamic-pituitary-adrenal (HPA) axis in children using TCS showed an overall good safety profile with a few cases demonstrating HPA suppression associated with use of potent TCS. Reports on effects of growth delay were inconclusive.$^{57}$ Clinical monitoring of potential sideeffects of TCS is sufficient and routine monitoring of systemic side-effects is not recommended. Steroid phobia is a common cause of failure of treatment. ${ }^{58,59}$ Parental concerns should be addressed to ensure adherence to treatment. ${ }^{60}$ Systematic review of seven case-control and cohort studies on pregnant women using TCS did not demonstrate an association of TCS with congenital abnormality or adverse outcome of pregnancy. ${ }^{61}$

\section{Wet-wrap}

Use of wet-wrap treatment was first described in detail in the early 1990s. Wet-wrap treatment involved application of TCS, with or without dilution, and emollients under layers of wet dressings. The principles of action included increase in TCS effects under occlusion, maintenance of skin hydration, cooling of inflamed skin, and reduction of scratching. ${ }^{62}$ Devillers and Oranje ${ }^{63}$ reviewed 10 small-scale studies with two RCTs and eight observation studies of wet-wrap treatment in children with moderate-to-severe eczema. All except one study applied undiluted mild TCS (hydrocortisone) or diluted mild-to-potent steroid (1:5 to 1:50 dilution) cream or ointment under two layers (one wet layer and one dry layer) of tubular bandages, maintained for 3 to 24 hours a day for a period of 2 to 14 days. There were variations in the type of steroid, emollient, and dressing used for wet-wrap, but all studies reported improvement in eczema scores. ${ }^{63}$ One study used emollients combined with $0.5 \%$ chlorhexidine and also showed mild improvement in SCORAD (SCORing Atopic Dermatitis) score after 3 days of treatment. A recent RCT showed that wetwrap with diluted $1 \%$ mometasone ointment had a better outcome and acted faster than emollients only. ${ }^{64}$ The most common reported adverse effects include discomfort, mostly due to chills, and folliculitis more commonly caused by ointment. Six out of the 10 studies reported a temporary decrease in early morning serum cortisol that normalised afterwards. ${ }^{63}$ Most experts recommended wet-wrap with diluted steroids as a short-term second-line treatment for severe eczema after infection was controlled. A set of practice guidelines on wetwrap treatment was published by the same group of authors with a detailed description of methodology and materials used. ${ }^{62}$ Nonetheless climacteric and personal issues limit the usefulness of wet-wrap treatment outside of the hospital setting. ${ }^{65}$

\section{Topical immunomodulants}

Topical calcineurin inhibitors (TCI) are ascomycin macrolactam derivatives produced by Streptomyces strains of bacterium. Topical calcineurin inhibitors act through inhibition of calcineurin function and hence reduce the production and release of proinflammatory cytokines in AD. Pimecrolimus cream $1 \%$ and tacrolimus ointment $0.03 \%$ are licensed for use in patients older than 2 years. Tacrolimus ointment $(0.1 \%)$ is recommended for use only over the age of 15 years and it remains part of the current recommendations by the US Food and Drug Administration (FDA). ${ }^{66-69}$ Short-term (3-12 weeks) and long-term (up to 1 year) studies of both TCIs showed that TCIs were significantly more effective than vehicle. ${ }^{40-42}$ Tacrolimus studies included 
mostly patients with moderate-to-severe $\mathrm{AD}$ and pimecrolimus studies focused on mild-to-moderate AD. ${ }^{66-68}$ There is strong evidence that TCIs have a steroid-sparing effect and long-term use of up to 12 months can prevent flares. ${ }^{66}$ Topical calcineurin inhibitors are particularly useful for sensitive sites including the face, neck, and skin flexures. Tacrolimus has been objectively shown to reduce itch and ameliorate sleep disturbance. ${ }^{70}$

Three studies that directly compared the efficacy of pimecrolimus and tacrolimus involved mainly children with mild-to-severe $\mathrm{AD}$ and showed that tacrolimus was more effective than pimecrolimus. ${ }^{66,68}$ In comparing TCI and TCS, a few short-term paediatric studies showed that $0.03 \%$ and $0.1 \%$ tacrolimus ointment was more effective than $1 \%$ hydrocortisone acetate cream or ointment. ${ }^{66,68}$ Two paediatric studies showed that $1 \%$ pimecrolimus is more effective than $1 \%$ hydrocortisone acetate and $0.1 \%$ triamcinolone acetate. ${ }^{68}$ One adult study showed that pimecrolimus was less effective than moderate TCS. ${ }^{67}$

In long-term studies of children and adults, TCIs were well tolerated. The most common sideeffects were local irritation, erythema, or pruritus. ${ }^{66}$ There was no evidence of increase in skin infections or skin atrophy even when TCIs were applied under occlusion. Systemic absorption was low and serum level did not accumulate following application for up to 12 months. Nonetheless data from animal studies on the risks of cancer associated with TCIs and post-marketing reports of lymphoma and skin cancer led the US FDA to issue recommendations for TCIs as short-term non-continuous therapy of $\mathrm{AD}$ in non-immunocompromised patients aged 2 years or above, ${ }^{69}$ and approved a black-box warning label for the two TCIs pimecrolimus cream (1\%) and tacrolimus ointment $(0.03 \%$ and $0.1 \%)$ in $2006 .{ }^{66}$ Subsequently, the efficacy and safety of TCIs have been systematically reviewed by various authors and professional groups: most concluded that TCIs are safe without evidence of increased risk of malignancy. ${ }^{55,66,69,71,72}$ At the moment, data from available human case-control and cohort studies have identified no causal association of TCIs with malignancies although the long-term potential carcinogenic risks of TCIs remain uncertain. Most international guidelines recommend that clinicians alert patients/parents to the black-box warningbefore starting treatment. ${ }^{26,30,36}$ The latest guidelines of the American Academy of Dermatology recommend off-label use of $0.03 \%$ tacrolimus ointment and $1 \%$ pimecrolimus for patients younger than 2 years with mild-to-severe AD. ${ }^{30}$

\section{Proactive approach with topical anti-inflammatory therapy}

Atopic dermatitis is a chronic relapsing inflammatory condition. Use of topical anti-inflammatory medications (TCS or TCI) intermittently only during acute flares and maintenance therapy with emollients during periods of clinical remission has been a common treatment strategy. Nonetheless, visually normal skin may have subclinical inflammation and be prone to exacerbations. There has been a paradigm shift in the approach to prevent flares through low-dose topical maintenance and proactive therapy after stabilisation of an acute exacerbation. ${ }^{32,73}$ A systematic review identified eight RCTs of proactive treatment with four trials of tacrolimus, three trials of fluticasone propionate, and one of methylprednisolone aceponate in paediatric and adult patients suffering from moderate-to-severe AD. ${ }^{74}$ Study medications were applied once daily twice a week (except one study of tacrolimus with application 3 times a week) over a period up to 16 weeks and 40 weeks for TCS and TCI, respectively. The data showed that the proactive treatment approach was more efficacious in prevention of flares during the treatment period but long-term safety data are lacking. ${ }^{74}$ The results suggested that for a patient with moderate-to-severe eczema and chronic relapsing lesions, maintenance treatment with topical anti-inflammatory therapy twice a week may be a better strategy to prevent AD flares and TCS may be more effective than TCIs. ${ }^{74}$

\section{Topical sodium cromoglicate}

Sodium cromoglicate (SCG) has anti-allergic, antiitch, and anti-inflammatory properties. It has been used topically in the treatment of asthma, allergic rhinitis, and allergic conjunctivitis. Recently, the effect of a new formulation of 4\% SCG cutaneous emulsions was evaluated as treatment for children with AD. ${ }^{75} \mathrm{~A}$ meta-analysis of three multicentre RCTs involving 490 children with AD and mean age of 5.3 years compared the outcomes of application of SCG emulsion against vehicle over a 12-week period. ${ }^{75}$ There was significant improvement in SCORAD score within the treatment group and $4 \%$ SCG produced a more significant but clinically mild difference in SCORAD score of $-2.82(-5.36 ;-0.29)$, $\mathrm{P}=0.03 .^{75}$ Another RCT of 208 children aged 2 to 12 years over 12 weeks showed that 4\% SCG was more effective in terms of greater improvement in SCORAD and SASSAD (Six Area, Six Sign Atopic Dermatitis) severity scores and reduced use of topical steroids during treatment periods. ${ }^{76}$ These results suggested that $4 \%$ SCG emulsion could be an effective treatment for children with AD.

\section{Antimicrobials and antiseptics}

There is no doubt that Staphylococcus aureus is linked to AD and treatment with short-course oral antibiotics in infected $\mathrm{AD}$ is a common practice 
despite the lack of supportive evidence. ${ }^{77,78} \mathrm{~A}$ systematic review included 26 short-term lowquality studies of $1229 \mathrm{AD}$ participants and compared various interventional strategies to reduce $S$ aureus infection, including oral antibiotics, topical antibiotics, or topical anti-septics. ${ }^{79}$ The authors concluded that anti-staphylococcal strategies can reduce the amount of bacteria in skin but the clinical benefit, especially in non-infected $\mathrm{AD}$, remains uncertain. Large-scale long-term good-quality studies are needed to study clinical outcomes and adverse effects. One study involved 31 children (6 months to 17 years) with moderateto-severe $\mathrm{AD}$ and evidence of bacterial infection who were randomised to use diluted bleach bath of $0.005 \%$ sodium hypochlorite twice per week plus nasal mupirocin 5 days per month for 3 months. ${ }^{80}$ Bacteria count was reduced and there was significant improvement in mean eczema EASI (Eczema Area and Severity Index) scores compared with placebo at 1 month and 3 months. ${ }^{80}$ Recent guidelines have included diluted bleach bath and nasal mupirocin as a recommended treatment for patients with moderate-to-severe $\mathrm{AD}$ and clinical signs of secondary bacterial infection. ${ }^{30,34,40}$

\section{Antihistamines}

Relief of itch will help to break the itch-scratch cycle' in AD. Despite the widespread use of first- and second-generation $\mathrm{H} 1$ antihistamines in $\mathrm{AD}$, there is no strong evidence that oral antihistamines are effective anti-pruritics. ${ }^{81}$ They are safe to use and their sedative effects, where present, may be useful to promote better sleep quality.

\section{Systemic immunomodulating therapy}

In patients with moderate-to-severe eczema who fail to respond to topical therapy, systemic immunomodulating agents have been prescribed as off-label medications. The European Treatment of Severe Atopic Eczema in Children Taskforce conducted a survey on the use of systemic therapy across eight European countries. ${ }^{82}$ Overall, 343 consultant physicians responded with $89.2 \%$ dermatologists: $71 \%$ would initiate systemic immunosuppression for children with severe atopic eczema. Cyclosporin A (CsA; 43.0\%) was the most popular first-line drug followed by oral corticosteroids (30.7\%) and azathioprine (AZA; 21.7\%); CsA (33.6\%) and AZA (28.7\%) were the two most commonly used as second-line medication, while methotrexate (MTX) was ranked as the most popular third-line drug (26.2\%). ${ }^{82}$ Around half of the respondents $(53.7 \%)$ replied that they routinely test and treat cutaneous infection prior to starting systemic treatment and $78.3 \%$ used penicillins as the first choice of antibiotics. ${ }^{82}$ Roekevisch et $\mathrm{al}^{83}$ recently published an updated systematic review based on Grading of Recommendations, Assessment, Development and Evaluation (GRADE) methodology, on the efficacy and safety of 12 systemic treatment interventions for moderate-to-severe AD. Overall, 34 RCTs were selected comprising a total of 1653 paediatric and adult patients. It concluded that CsA, AZA, and MTX could be recommended as systemic treatment for refractory AD. There were 14 short-term and long-term studies on CsA that all demonstrated improvement in clinical outcomes, and short-term studies had the largest number of subjects for the strongest recommendations. Although the authors recommended CsA as a first-line therapy, AZA as second-line, and MTX as third-line systemic treatment for moderate-to-severe $\mathrm{AD}$, there was a lack of data on direct comparison of the efficacy of these three agents. ${ }^{83}$ In addition, paediatric data were scant and the long-term safety profile of these medications in AD patients was uncertain. Clinicians should consider patient factors and potential risks when prescribing any one of the above systemic agents. Recommendations were not possible for other systemic treatment including mycophenolate mofetil, intravenous gamma globulin, montelukast, systemic calcineurin inhibitors, and systemic corticosteroids due to limited or poor-quality data. Systemic oral glucocorticosteroids were used for years but the high risk of flares after cessation of treatment and unfavourable risk-benefit profile limited their clinical use, especially in children.

\section{Cyclosporin $A$}

Cyclosporin A inhibits activation of $\mathrm{T}$ cells and has been originally used to control graft rejection in transplant patients. With accumulating experience and data about its role in the treatment of severe $\mathrm{AD}$, international guidelines recommend CsA as a systemic immune therapy to consider for chronic severe eczema in children and adults who have failed to respond to topical therapy. ${ }^{28,33,34}$ Five RCTs with 146 participants compared CsA with placebo and revealed an improvement in clinical eczema severity scores by $53 \%$ to $95 \%$ after treatment from 10 days to 8 weeks. ${ }^{84}$ One study also showed a decrease in surface area of involvement. ${ }^{84}$ In a systematic review of 15 controlled and uncontrolled studies including 602 patients, cyclosporin consistently decreased the severity of atopic eczema. ${ }^{83}$ Analysis of 12 studies found a dose-related response at 2-week treatment with a pooled mean decrease in disease severity of $22 \%$ (95\% confidence interval [CI], 8-36\%) with low-dose cyclosporin $(<3 \mathrm{mg} / \mathrm{kg})$ and $40 \%(95 \%$ $\mathrm{CI}, 29-51 \%)$ at dosages of $\geq 4 \mathrm{mg} / \mathrm{kg}$. After 6 to 8 weeks, the relative effectiveness was $55 \%$ (95\% CI, 48-62\%). ${ }^{83} \mathrm{~A}$ few studies compared CsA with other agents and showed it to be more effective than oral prednisolone, intravenous immunoglobulin (Ig), and phototherapy. ${ }^{81}$ There were four open-label paediatric 
and adult long-term studies for CsA of up to 12 months showing sustained effects with continuous use. ${ }^{81}$ The potential side-effects of CsA in AD are similar to those in other conditions that require CsA therapy. They include infection, nephrotoxicity, hypertension, hypertrichosis, gingival hyperplasia, increased risks of skin cancer and lymphoma. Patients should have their blood pressure checked at every visit with renal and liver function tests, and blood cell counts performed every 2 weeks for the first 2 to 3 months of treatment, then monthly thereafter. The usual dosage recommendations of CsA ranged from 2.5 to $6 \mathrm{mg} / \mathrm{kg} /$ day although a higher initial starting dosage of $5 \mathrm{mg} / \mathrm{kg} /$ day demonstrated a more rapid response and adverse effects were not reported to be dose-related. Nonetheless on balance, it is advisable to start at a lower dose of 2.5 to $3 \mathrm{mg} / \mathrm{kg} /$ day and titrate stepwise to ascertain the lowest maintenance dose for control with serum creatinine within $25 \%$ of baseline. ${ }^{28,33}$ As the long-term safety profile and relapse rate of CsA use in AD patients, in particular paediatric patients, is uncertain, it may be more suitable as a short-term therapy. Concomitant use of other immunosuppressants or phototherapy is not recommended.

\section{Azathioprine}

Azathioprine is a purine analogue with immunomodulating properties. Similar to CsA, it was initially developed in the 1960s for treatment of graft-versus-host disease. In the past 20 years evidence has accumulated for its use as a steroid-sparing agent in the treatment of severe recalcitrant AD. Two RCTs in 98 adult patients found better improvement in SASSAD score following AZA treatment for up to 12 weeks compared with placebo. ${ }^{83}$ A study comparing AZA with MTX showed similar improvement in symptom scores and quality of life after 12 weeks of treatment. ${ }^{83}$ Paediatric data were limited but a few observational studies showed promising results. A local retrospective study of 17 children and young adults showed improved SCORAD score at 3 months and 6 months of treatment. ${ }^{85}$ Dosage recommendations ranged from 1 to $3 \mathrm{mg} / \mathrm{kg} / \mathrm{day}$. Mild side-effects such as gastro-intestinal intolerance and headache are common. Serious sideeffects have been linked to genetic polymorphism of thiopurine methyltransferase (TPMT), an important enzyme in the metabolism of AZA. Individuals with homozygous TPMT mutations (low or absent TPMT activity) are prone to develop life-threatening myelosuppression while those with supra-normal TPMT activity may respond less well to treatment but could be at higher risk of hepatotoxicity. ${ }^{33}$ The dosing of AZA can also be guided by TPMT activity as patients with TPMT activity at the heterozygous range respond at the low dosage range with no increase in toxicity. ${ }^{86}$ Measurement of TPMT level before initiation of treatment with AZA is generally recommended and regular monitoring of blood cell counts and liver function tests is indicated for all patients during the course of treatment. ${ }^{28,33}$

\section{Methotrexate}

Methotrexate is a folic acid antagonist with T-cell suppression, approved for use in two dermatological conditions including psoriasis and advanced mycosis fungoides. A few small-scale retrospective studies showed that MTX was effective in the treatment of AD adult patients. ${ }^{33,83}$ There were only a few paediatric retrospective case series demonstrating that MTX treatment in AD was safe, effective, and well tolerated. ${ }^{33}$ Recently, El-Khalawany et $\mathrm{al}^{87}$ published the first RCT study comparing low-dose MTX (7.5 mg/week) and CsA (2.5 mg/kg/week) in 40 Egyptian children with severe AD. At the end of 12 weeks, there was a similar reduction in mean SCORAD score for MTX and CsA. The study showed $20 \%$ to $30 \%$ of patients on MTX had minor adverse effects of anaemia, fatigue and diarrhoea, and $20 \%$ had abnormal liver but none had significant liver toxicity or other adverse effects that required adjustment in treatment.

\section{Phototherapy}

Garritsen et $\mathrm{al}^{88}$ performed the first systematic review of phototherapy in AD patients using GRADE system. Nineteen RCT studies of various modalities of photo(chemo)therapies with treatment duration of 10 days to 40 weeks involving 905 participants (age range, 8-83 years) were included. Metaanalysis could not be performed as most studies were small scale with wide heterogeneity in quality and methodology. The authors concluded that narrowband ultraviolet B (NB-UVB) and ultraviolet A1 (UVA1) seemed to be the most effective forms of phototherapy. ${ }^{88}$ Psoralen plus UVA (PUVA) was also an effective option but generally not the first choice due to its association with side-effects. Other treatment modalities including full-spectrum UVA, broadband UVB, and full-spectrum light therapy were considered less effective treatment. Most forms of phototherapy were mainly used for treatment of chronic lichenified forms of moderateto-severe AD, except for high-dose UVA1 that was also effective for treatment of acute flares. ${ }^{88}$ In general, long-term exposure to UV light increases the risk of skin cancer. One report highlighted an increased risk of non-melanoma skin cancer in children with psoriasis on PUVA treatment. ${ }^{33}$ There are, however, no data about the long-term risk of developing cancer in children undergoing NB-UVB. ${ }^{89}$ Common reported side-effects included xerosis cutis, erythema, burning sensations, and skin 
pigmentation. Ultraviolet A treatment, particularly with the addition of oral psoralen (PUVA), was more likely to be associated with side-effects of photosensitivity, cataract formation, folliculitis, and photo-onycholysis. Side-effects of oral psoralen include headache, nausea, vomiting, and, rarely, hepatotoxicity. Concomitant therapy with emollients and TCS may be used for control of acute flare and maintenance therapy but TCI should be avoided. In current guidelines, phototherapy is considered a safe and effective second-line treatment for moderateto-severe AD. ${ }^{28,33,34}$ Available evidence supports NB-UVB as the preferred treatment with moderatedose UVA1 as an alternative treatment, while highdose UVA1 may be considered in the acute phase. Clinical response to the type, dose, and duration of phototherapy varied widely and treatment regimens have to be individualised.

\section{Dietary interventions}

The relationship of food allergy with $\mathrm{AD}$ is complex. $^{90,91}$ Immunoglobulin $\mathrm{E}$ sensitisation to food has been reported in about $40 \%$ to $90 \%$ of patients with moderate-to-severe $\mathrm{AD}$, but positive skin prick testing and specific IgE levels have poor predictive value for immediate or delayed eczematous reactions. ${ }^{91,92}$ Dietary avoidance based on food-specific IgA or IgG testing is not efficacious in ameliorating disease severity. ${ }^{93}$ Food allergens trigger eczema exacerbations especially in infants and young children but there is a lack of evidence that food allergens cause AD. A systematic review of the effects in nine trials of an elimination diet on existing eczema showed that there was no evidence to support the use of egg-free or milk-free dietary exclusion for unselected AD patients and no benefit for elemental or food-restricted diet in general. ${ }^{94}$ An exclusion diet is more likely to be useful in patients with a clinical history of IgE-mediated allergic reactions and young patients with severe disease. ${ }^{94}$ An elimination diet should not be continued if no improvement is observed after 3 to 4 weeks. $^{92}$

\section{Allergen-specific immunotherapy}

Administration of allergen-specific immunotherapy (ASIT) through giving repeated incremental subcutaneous (SCIT) or sublingual (SLIT) doses of allergen may induce immune tolerance in patients sensitised to allergens. In patients with $\mathrm{AD}$, the best evidence for use of ASIT is with the house dust mite (HDM) allergen. In a systematic review, eight RCTs that comprised a total of $385 \mathrm{AD}$ subjects sensitised to HDM were given ASIT: six studies used SCIT and two studies used SLIT for a treatment period of 4 to 36 months. It was found that ASIT had a significant positive effect on clinical outcome of AD. ${ }^{95}$ The effect was significant in subgroup analysis for long-term treatment longer than 1 year, severe $\mathrm{AD}$ and SCIT, but insignificant for children only and SLIT. ${ }^{95}$ Nonetheless with the limitations of smallscale heterogeneous studies, it is not possible to make specific recommendations on the use of ASIT. Current evidence suggests that ASIT may be one of the treatment options in patients with severe AD sensitised to HDM. ${ }^{28,34}$

\section{Chinese herbal medicine}

The beneficial effects of Chinese herbal medicine (CHM) in children with $\mathrm{AD}$ have not been consistently demonstrated. ${ }^{96,97}$ Meta-analyses have been performed by Cochrane reviews and show no conclusive evidence that oral intake of most Chinese herbs or Chinese herbal formulae used in the included studies could improve eczema. ${ }^{96}$ Further, they could not find convincing evidence that topical application of CHM, used alone or in conjunction with oral administration of Chinese herbal formula, could reduce the severity of eczema in children or adults. Even though the included studies claimed that there were statistically significant differences in the outcome measures for the CHM treatment groups compared with the control groups, these claims could not be substantiated due to a low strength of evidence and high risk of bias. ${ }^{98}$

In a series of studies and a RCT, Hon et $\mathrm{al}^{99-102}$ demonstrated that a PentaHerbs concoction improved quality of life in children with moderateto-severe eczema. Experts in the Cochrane reviews have suggested that well-designed, adequately powered trials are needed to evaluate the efficacy and safety of CHM for managing eczema. ${ }^{96,103}$

\section{Psychological and educational interventions}

Psychological symptoms of stress, anxiety, and depression are prevalent among eczema patients and correlate with quality-of-life impairment. ${ }^{104}$ Psychological and educational interventions are complementary to other therapeutic approaches to help patients and carers to cope with this chronic condition. These interventions were reviewed systematically and recently updated by the Cochrane Skin Group in 2014. ${ }^{105}$ Ten studies were included with nine studies reviewing predominantly parentfocused educational interventions and one focused on child-centred psychological interventions. ${ }^{105}$ One large study of 992 subjects revealed that the study group who received age-appropriate group education in six standardised sessions had significant improvement in disease severity score and quality of life. ${ }^{105}$ Due to the heterogeneity of interventions and outcome, the authors concluded that it was impossible to draw definitive conclusions and there was a need for further research, in particular standalone psychological interventions. 


\section{Conclusion}

Management of $\mathrm{AD}$ has remained challenging, often not because of the lack of effective treatment but of non-adherence and unrealistic expectations on the part of patients or their parents. Detailed evaluation of disease severity, treatment history, and its impact on patients' and parents' quality of life will determine the individual success of management for this complex atopic disease.

\section{References}

1. Simpson EL, Hanifin JM. Atopic dermatitis. J Am Acad Dermatol 2005;53:115-28.

2. Leung AK, Hon KL, Robson WL. Atopic dermatitis. Adv Pediatr 2007;54:241-73.

3. Leung R, Wong G, Lau J, et al. Prevalence of asthma and allergy in Hong Kong schoolchildren: an ISAAC study. Eur Respir J 1997;10:354-60.

4. Leung DY, Nicklas RA, Li JT, et al. Disease management of atopic dermatitis: an updated practice parameter. Joint Task Force on Practice Parameters. Ann Allergy Asthma Immunol 2004;93(3 Suppl 2):S1-21.

5. Simpson EL. Atopic dermatitis: a review of topical treatment options. Curr Med Res Opin 2010;26:633-40.

6. Shaw TE, Currie GP, Koudelka CW, Simpson EL. Eczema prevalence in the United States: data from the 2003 National Survey of Children's Health. J Invest Dermatol 2011;131:67-73.

7. Leung AK, Barber KA. Managing childhood atopic dermatitis. Adv Ther 2003;20:129-37.

8. Wong GW, Leung TF, Ko FW, et al. Declining asthma prevalence in Hong Kong Chinese schoolchildren. Clin Exp Allergy 2004;34:1550-5.

9. Wong GW, Leung TF, Ma Y, Liu EK, Yung E, Lai CK. Symptoms of asthma and atopic disorders in preschool children: prevalence and risk factors. Clin Exp Allergy 2007;37:174-9.

10. Chamlin SL, Frieden IJ, Williams ML, Chren MM. Effects of atopic dermatitis on young American children and their families. Pediatrics 2004;114:607-11.

11. Hon KL, Leung TF, Wong KY, Chow CM, Chuh A, Ng PC. Does age or gender influence quality of life in children with atopic dermatitis? Clin Exp Dermatol 2008;33:705-9.

12. Grillo M, Gassner L, Marshman G, Dunn S, Hudson P. Pediatric atopic eczema: the impact of an educational intervention. Pediatr Dermatol 2006;23:428-36.

13. Hanifin J, Rajka G. Diagnostic features of atopic dermatitis. Acta Derm Venereol (Stockh) 1980;2:44-7.

14. Williams HC, Burney PG, Pembroke AC, Hay RJ. The U.K. Working Party's Diagnostic Criteria for Atopic Dermatitis. III. Independent hospital validation. Br J Dermatol 1994;131:406-16.

15. Leung DY, Jain N, Leo HL. New concepts in the pathogenesis of atopic dermatitis. Curr Opin Immunol 2003; 15:634-8.

16. Abramovits W. Atopic dermatitis. J Am Acad Dermatol 2005;53(1 Suppl 1):S86-93.

17. Hon KL, Wang SS, Leung TF. The atopic march: from skin to the airways. Iran J Allergy Asthma Immunol 2012;11:737.

18. Marenholz I, Nickel R, Ruschendorf F, et al. Filaggrin loss- of-function mutations predispose to phenotypes involved in the atopic march. J Allergy Clin Immunol 2006;118:86671.

19. Palmer $\mathrm{CN}$, Irvine $\mathrm{AD}$, Terron-Kwiatkowski $\mathrm{A}$, et al. Common loss-of-function variants of the epidermal barrier protein filaggrin are a major predisposing factor for atopic dermatitis. Nat Genet 2006;38:441-6.

20. Sandilands A, Terron-Kwiatkowski A, Hull PR, et al. Comprehensive analysis of the gene encoding filaggrin uncovers prevalent and rare mutations in ichthyosis vulgaris and atopic eczema. Nat Genet 2007;39:650-4.

21. Sandilands A, Smith FJ, Irvine AD, McLean WH. Filaggrin's fuller figure: a glimpse into the genetic architecture of atopic dermatitis. J Invest Dermatol 2007;127:1282-4.

22. Ching G, Hon KL, Np PC, Leung TF. Filaggrin null mutations in childhood atopic dermatitis among the Chinese. Int J Immunogenet 2009;36:251-4.

23. Jungersted JM, Scheer H, Mempel M, et al. Stratum corneum lipids, skin barrier function and filaggrin mutations in patients with atopic eczema. Allergy 2010;65:911-8.

24. Hon KL, Leung AK, Barankin B. Barrier repair therapy in atopic dermatitis: an overview. Am J Clin Dermatol 2013;14:389-99.

25. Akdis CA, Akdis M, Bieber T, et al. Diagnosis and treatment of atopic dermatitis in children and adults: European Academy of Allergy and Clinical Immunology/ American Academy of Allergy, Asthma and Immunology/ PRACTALL Consensus Report. Allergy 2006;61:969-87.

26. Darsow U, Wollenberg A, Simon D, et al. ETFAD/EADV eczema task force 2009 position paper on diagnosis and treatment of atopic dermatitis. J Eur Acad Dermatol Venereol 2010;24:317-28.

27. Ring J, Alomar A, Bieber T, et al. Guidelines for treatment of atopic eczema (atopic dermatitis) Part I. J Eur Acad Dermatol Venereol 2012;26:1045-60.

28. Ring J, Alomar A, Bieber T, et al. Guidelines for treatment of atopic eczema (atopic dermatitis) Part II. J Eur Acad Dermatol Venereol 2012;26:1176-93.

29. Hanifin JM, Cooper KD, Ho VC, et al. Guidelines of care for atopic dermatitis, developed in accordance with the American Academy of Dermatology (AAD)/American Academy of Dermatology Association "Administrative Regulations for Evidence-Based Clinical Practice Guidelines". J Am Acad Dermatol 2004;50:391-404.

30. Eichenfield LF, Tom WL, Berger TG, et al. Guidelines of care for the management of atopic dermatitis: section 2 . Management and treatment of atopic dermatitis with topical therapies. J Am Acad Dermatol 2014;71:116-32.

31. Eichenfield LF, Tom WL, Chamlin SL, et al. Guidelines of care for the management of atopic dermatitis: section 1 . Diagnosis and assessment of atopic dermatitis. J Am Acad Dermatol 2014;70:338-51.

32. Sidbury R, Tom WL, Bergman JN, et al. Guidelines of care for the management of atopic dermatitis: section 4 . Prevention of disease flares and use of adjunctive therapies and approaches. J Am Acad Dermatol 2014;71:1218-33.

33. Sidbury R, Davis DM, Cohen DE, et al. Guidelines of care for the management of atopic dermatitis: section 3. Management and treatment with phototherapy and systemic agents. J Am Acad Dermatol 2014;71:327-49.

34. Schneider L, Tilles S, Lio P, et al. Atopic dermatitis: a practice parameter update 2012. J Allergy Clin Immunol 2013;131:295-9.e1-27. 
35. Saeki H, Furue M, Furukawa F, et al. Guidelines for management of atopic dermatitis. J Dermatol 2009;36:56377.

36. Lewis-Jones S, Mugglestone MA; Guideline Development Group. Management of atopic eczema in children aged up to 12 years: summary of NICE guidance. BMJ 2007;335:1263-4.

37. Katayama I, Kohno Y, Akiyama K, et al. Japanese Guideline for Atopic Dermatitis 2014. Allergol Int 2014;63:377-98.

38. Baker M. NICE guidance points the way to tackling eczema in children. Community Pract 2013;86:40.

39. Eichenfield LF. Consensus guidelines in diagnosis and treatment of atopic dermatitis. Allergy 2004;59 Suppl 78:86-92.

40. Leung TN, Chow CM, Chow MP, et al. Clinical guidelines on management of atopic dermatitis in children. Hong Kong J Paediatr 2013;18:96-104.

41. Hon KL, Ching GK, Leung TF, Choi CY, Lee KK, Ng PC. Estimating emollient usage in patients with eczema. Clin Exp Dermatol 2010;35:22-6.

42. Hon KL, Wang SS, Lau Z, et al. Pseudoceramide for childhood eczema: does it work? Hong Kong Med J 2011;17:132-6.

43. Hon KL, Wang SS, Pong NH, Leung TF. The ideal moisturizer: a survey of parental expectations and practice in childhood-onset eczema. J Dermatolog Treat 2013;24:712 .

44. Hon KL, Leung AK. Use of ceramides and related products for childhood-onset eczema. Recent Pat Inflamm Allergy Drug Discov 2013;7:12-9.

45. Hon KL, Pong NH, Wang SS, Lee VW, Luk NM, Leung TF. Acceptability and efficacy of an emollient containing ceramide-precursor lipids and moisturizing factors for atopic dermatitis in pediatric patients. Drugs R D 2013;13:37-42.

46. Miller DW, Koch SB, Yentzer BA, et al. An over-thecounter moisturizer is as clinically effective as, and more cost-effective than, prescription barrier creams in the treatment of children with mild-to-moderate atopic dermatitis: a randomized, controlled trial. J Drugs Dermatol 2011;10:531-7.

47. Tsang M, Guy RH. Effect of Aqueous Cream BP on human stratum corneum in vivo. Br J Dermatol 2010;163:954-8.

48. Mohammed D, Matts PJ, Hadgraft J, Lane ME. Influence of Aqueous Cream BP on corneocyte size, maturity, skin protease activity, protein content and transepidermal water loss. Br J Dermatol 2011;164:1304-10.

49. Danby SG, Al-Enezi T, Sultan A, Chittock J, Kennedy $\mathrm{K}$, Cork MJ. The effect of aqueous cream BP on the skin barrier in volunteers with a previous history of atopic dermatitis. Br J Dermatol 2011;165:329-34.

50. Simpson EL, Chalmers JR, Hanifin JM, et al. Emollient enhancement of the skin barrier from birth offers effective atopic dermatitis prevention. J Allergy Clin Immunol 2014;134:818-23.

51. Horimukai K, Morita K, Narita M, et al. Application of moisturizer to neonates prevents development of atopic dermatitis. J Allergy Clin Immunol 2014;134:824-30.e6.

52. Hoare C, Li Wan PA, Williams H. Systematic review of treatments for atopic eczema. Health Technol Assess 2000;4:1-191.

53. Baumer JH. Atopic eczema in children, NICE. Arch Dis Child Educ Pract Ed 2008;93:93-7.
54. Green C, Colquitt JL, Kirby J, Davidson P. Topical corticosteroids for atopic eczema: clinical and cost effectiveness of once-daily vs. more frequent use. $\mathrm{Br} \mathrm{J}$ Dermatol 2005;152:130-41.

55. Callen J, Chamlin S, Eichenfield LF, et al. A systematic review of the safety of topical therapies for atopic dermatitis. Br J Dermatol 2007;156:203-21.

56. Hengge UR, Ruzicka T, Schwartz RA, Cork MJ. Adverse effects of topical glucocorticosteroids. J Am Acad Dermatol 2006;54:1-15; quiz 16-8.

57. Haeck IM, Rouwen TJ, Timmer-de ML, de Bruin-Weller MS, Bruijnzeel-Koomen CA. Topical corticosteroids in atopic dermatitis and the risk of glaucoma and cataracts. J Am Acad Dermatol 2011;64:275-81.

58. Charman CR, Morris AD, Williams HC. Topical corticosteroid phobia in patients with atopic eczema. $\mathrm{Br} \mathrm{J}$ Dermatol 2000;142:931-6.

59. Hon KL, Kam WY, Leung TF, et al. Steroid fears in children with eczema. Acta Paediatr 2006;95:1451-5.

60. Hon KL, Tsang YC, Pong NH, et al. Correlations among steroid fear, acceptability, usage frequency, quality of life and disease severity in childhood eczema. J Dermatolog Treat 2015 Apr 20:1-8. Epub ahead of print.

61. Chi CC, Wang SH, Kirtschig G, Wojnarowska F. Systematic review of the safety of topical corticosteroids in pregnancy. J Am Acad Dermatol 2010;62:694-705.

62. Oranje AP, Devillers AC, Kunz B, et al. Treatment of patients with atopic dermatitis using wet-wrap dressings with diluted steroids and/or emollients. An expert panel's opinion and review of the literature. J Eur Acad Dermatol Venereol 2006;20:1277-86.

63. Devillers AC, Oranje AP. Efficacy and safety of 'wet-wrap' dressings as an intervention treatment in children with severe and/or refractory atopic dermatitis: a critical review of the literature. Br J Dermatol 2006;154:579-85.

64. Janmohamed SR, Oranje AP, Devillers AC, et al. The proactive wet-wrap method with diluted corticosteroids versus emollients in children with atopic dermatitis: a prospective, randomized, double-blind, placebo-controlled trial. J Am Acad Dermatol 2014;70:1076-82.

65. Hon KL, Wong KY, Cheung LK, et al. Efficacy and problems associated with using a wet-wrap garment for children with severe atopic dermatitis. J Dermatolog Treat 2007;18:301-5.

66. Kalavala M, Dohil MA. Calcineurin inhibitors in pediatric atopic dermatitis: a review of current evidence. Am J Clin Dermatol 2011;12:15-24.

67. El-Batawy MM, Bosseila MA, Mashaly HM, Hafez VS. Topical calcineurin inhibitors in atopic dermatitis: a systematic review and meta-analysis. J Dermatol Sci 2009;54:76-87.

68. Chen SL, Yan J, Wang FS. Two topical calcineurin inhibitors for the treatment of atopic dermatitis in pediatric patients: a meta-analysis of randomized clinical trials. J Dermatolog Treat 2010;21:144-56.

69. Berger TG, Duvic M, Van Voorhees AS, VanBeek MJ, Frieden IJ; American Academy of Dermatology Association Task Force. The use of topical calcineurin inhibitors in dermatology: safety concerns. Report of the American Academy of Dermatology Association Task Force. J Am Acad Dermatol 2006;54:818-23.

70. Hon KL, Lam MC, Leung TF, Chow CM, Wong E, Leung AK. Assessing itch in children with atopic dermatitis treated with tacrolimus: objective versus subjective 
assessment. Adv Ther 2007;24:23-8.

71. Ring J, Barker J, Behrendt $\mathrm{H}$, et al. Review of the potential photo-cocarcinogenicity of topical calcineurin inhibitors: position statement of the European Dermatology Forum. J Eur Acad Dermatol Venereol 2005;19:663-71.

72. Segal AO, Ellis AK, Kim HL. CSACI position statement: safety of topical calcineurin inhibitors in the management of atopic dermatitis in children and adults. Allergy Asthma Clin Immunol 2013;9:24.

73. Wollenberg A, Ehmann LM. Long term treatment concepts and proactive therapy for atopic eczema. Ann Dermatol 2012;24:253-60.

74. Schmitt J, von Kobyletzki L, Svensson A, Apfelbacher C. Efficacy and tolerability of proactive treatment with topical corticosteroids and calcineurin inhibitors for atopic eczema: systematic review and meta-analysis of randomized controlled trials. Br J Dermatol 2011;164:415-28.

75. Stevens MT, Edwards AM. The effect of $4 \%$ sodium cromoglicate cutaneous emulsion compared to vehicle in atopic dermatitis in children-A meta-analysis of total SCORAD scores. J Dermatolog Treat 2014 Jul 18:1-7. Epub ahead of print.

76. Berth-Jones J, Pollock I, Hearn RM, et al. A randomised, controlled trial of a $4 \%$ cutaneous emulsion of sodium cromoglicate in treatment of atopic dermatitis in children. J Dermatolog Treat 2014 Aug 7:1-6. Epub ahead of print.

77. Hon KL, Lam MC, Leung TF, et al. Clinical features associated with nasal Staphylococcus aureus colonisation in Chinese children with moderate-to-severe atopic dermatitis. Ann Acad Med Singapore 2005;34:602-5.

78. Hon KL, Wang SS, Lee KK, Lee VW, Fan LT, Ip M. Combined antibiotic/corticosteroid cream in the empirical treatment of moderate to severe eczema: friend or foe? J Drugs Dermatol 2012;11:861-4.

79. Bath-Hextall FJ, Birnie AJ, Ravenscroft JC, Williams HC. Interventions to reduce Staphylococcus aureus in the management of atopic eczema: an updated Cochrane review. Br J Dermatol 2010;163:12-26.

80. Huang JT, Abrams M, Tlougan B, Rademaker A, Paller AS. Treatment of Staphylococcus aureus colonization in atopic dermatitis decreases disease severity. Pediatrics 2009;123:e808-14.

81. Apfelbacher CJ, van Zuuren EJ, Fedorowicz Z, Jupiter A, Matterne U, Weisshaar E. Oral H1 antihistamines as monotherapy for eczema. Cochrane Database Syst Rev 2013;(2):CD007770.

82. Proudfoot LE, Powell AM, Ayis S, et al. The European TREatment of severe Atopic eczema in children Taskforce (TREAT) survey. Br J Dermatol 2013;169:901-9.

83. Roekevisch E, Spuls PI, Kuester D, Limpens J, Schmitt J. Efficacy and safety of systemic treatments for moderate-tosevere atopic dermatitis: a systematic review. J Allergy Clin Immunol 2014;133:429-38.

84. Schmitt J, Schmitt N, Meurer M. Cyclosporin in the treatment of patients with atopic eczema-a systematic review and meta-analysis. J Eur Acad Dermatol Venereol 2007;21:606-19.

85. Hon KL, Ching GK, Leung TF, Chow CM, Lee KK, Ng PC. Efficacy and tolerability at 3 and 6 months following use of azathioprine for recalcitrant atopic dermatitis in children and young adults. J Dermatolog Treat 2009;20:141-5.

86. Meggitt SJ, Gray JC, Reynolds NJ. Azathioprine dosed by thiopurine methyltransferase activity for moderate- to-severe atopic eczema: a double-blind, randomised controlled trial. Lancet 2006;367:839-46.

87. El-Khalawany MA, Hassan H, Shaaban D, Ghonaim N, Eassa B. Methotrexate versus cyclosporine in the treatment of severe atopic dermatitis in children: a multicenter experience from Egypt. Eur J Pediatr 2013;172:351-6.

88. Garritsen FM, Brouwer MW, Limpens J, Spuls PI. Photo(chemo)therapy in the management of atopic dermatitis: an updated systematic review with implications for practice and research. Br J Dermatol 2014;170:501-13.

89. Grundmann SA, Beissert S. Modern aspects of phototherapy for atopic dermatitis. J Allergy (Cairo) 2012;2012:121797.

90. Hon KL, Leung TF, Kam WY, Lam MC, Fok TF, Ng PC. Dietary restriction and supplementation in children with atopic eczema. Clin Exp Dermatol 2006;31:187-91.

91. Hon KL, Chan IH, Chow CM, et al. Specific IgE of common foods in Chinese children with eczema. Pediatr Allergy Immunol 2011;22:50-3.

92. Campbell DE. Role of food allergy in childhood atopic dermatitis. J Paediatr Child Health 2012;48:1058-64.

93. Hon KL, Poon TC, Pong NH, et al. Specific IgG and IgA of common foods in Chinese children with eczema: friend or foe. J Dermatolog Treat 2013;25:462-6.

94. Bath-Hextall F, Delamere FM, Williams HC. Dietary exclusions for improving established atopic eczema in adults and children: systematic review. Allergy 2009;64:25864.

95. Bae JM, Choi YY, Park CO, Chung KY, Lee KH. Efficacy of allergen-specific immunotherapy for atopic dermatitis: a systematic review and meta-analysis of randomized controlled trials. J Allergy Clin Immunol 2013;132:110-7.

96. Zhang W, Leonard T, Bath-Hextall F, et al. Chinese herbal medicine for atopic eczema. Cochrane Database Syst Rev 2005;(2):CD002291.

97. Hon KL, Leung TF, Yau HC, Chan T. Paradoxical use of oral and topical steroids in steroid-phobic patients resorting to traditional Chinese medicines. World J Pediatr 2012;8:2637.

98. Gu S, Yang AW, Xue CC, et al. Chinese herbal medicine for atopic eczema. Cochrane Database Syst Rev 2013;(9):CD008642.

99. Hon KL, Leung TF, Wong Y, et al. A pentaherbs capsule as a treatment option for atopic dermatitis in children: an open-labeled case series. Am J Chin Med 2004;32:941-50.

100.Hon KL, Leung TF, Ng PC, et al. Efficacy and tolerability of a Chinese herbal medicine concoction for treatment of atopic dermatitis: a randomized, double-blind, placebocontrolled study. Br J Dermatol 2007;157:357-63.

101.Hon KL, Lo W, Cheng WK, et al. Prospective selfcontrolled trial of the efficacy and tolerability of a herbal syrup for young children with eczema. J Dermatolog Treat 2012;23:116-21.

102.Hon KL, Chan BC, Leung PC. Chinese herbal medicine research in eczema treatment. Chin Med 2011;6:17.

103.Ernst E. Homeopathy for eczema: a systematic review of controlled clinical trials. Br J Dermatol 2012;166:1170-2.

104.Hon KL, Pong NH, Poon TC, et al. Quality of life and psychosocial issues are important outcome measures in eczema treatment. J Dermatolog Treat 2015;26:83-9.

105.Ersser SJ, Cowdell F, Latter S, et al. Psychological and educational interventions for atopic eczema in children. Cochrane Database Syst Rev 2014;(1):CD004054. 